\title{
Vitamin D Status in Hospitalised Children (2 Months to 5 Years) with Respiratory Illnesses - An Analytical Case Control Study
}

Prateek Sinha ${ }^{1 *}$, Santanu Deb ${ }^{2}$, Palash Ranjan Gogoi ${ }^{2}$

${ }^{1}$ Department of Pediatrics and Neonatology, Samford Hospital, Ranchi, Jharkhand, India
${ }^{2}$ Department of Pediatrics and Neonatology, Nazareth Hospital, Shillong, Meghalaya, India

DOI: $10.36347 /$ sjams.2021.v09i01.003

| Received: 17.12.2020 | Accepted: 31.12.2020 | Published: 04.01.2021

*Corresponding author: Prateek Sinha

Abstract

Original Research Article

Vitamin D is a steroid hormone synthesized in the skin through sunlight exposure or ingested through the diet. In its active form, 1, 25-dihydroxyvitamin $\mathrm{D}(1,25[\mathrm{OH}] \mathrm{D})$ is involved in defense against viral, bacterial, and mycobacterial infections in pulmonary tissues and in down-regulating inflammation by decreasing chemokine and cytokine production. The anti inflammatory actions of $1,25(\mathrm{OH}) \mathrm{D}$ have also been shown in in vitro models of lung tissue; when inflamed airway smooth muscle cells are treated with increasing doses of $1,25(\mathrm{OH}) \mathrm{D}$, they exhibit dose-dependent decreases in the production of inflammatory cytokine. Methods: This was an Analytical, Case control study carried out in pediatrics departments of Nazareth hospital, Shillong, Meghalaya, India. Results: Mean Vitamin D levels were normally distributed among the children: the mean vitamin D level was $26.50 \mathrm{ng} / \mathrm{mL}$ (SE: 0.95) and the median vitamin D level was $26.27 \mathrm{ng} / \mathrm{mL}$. The mean for cases and controls were, respectively, $25.98 \mathrm{ng} / \mathrm{mL}$ and $27.02 \mathrm{ng} / \mathrm{mL}$. In entire cohort, $49.5 \%$ of all children were vitamin D deficient and among them $14 \%$ were severe vitamin D deficient. No significant difference in mean serum $25(\mathrm{OH})$ D level was found among cases as compared to controls, no significant association was found between respiratory diseases in children of 2 month to 60 months with low serum vitamin D levels. Respiratory complications were found more in Vitamin D deficient group, P-value calculated by chisquare test was "0.02" \& was significant, suggesting association between Vitamin D deficiency \& respiratory complication. Odds ratio was "7.7". Conclusion: No significant relationship was found between vitamin D levels with any of the following: respiratory illnesses vs non respiratory, male vs females. Respiratory complications were found more in Vitamin D deficient group. Correlation was found between age \& vitamin D level, suggesting association between Vitamin D levels \& age.

Keywords: Vitamin D, Respiratory illness, Vitamin D Deficiency, Hospital, Pediatrics.

Copyright $($ C) 2021 The Author(s): This is an open-access article distributed under the terms of the Creative Commons Attribution 4.0 International License (CC BY-NC 4.0) which permits unrestricted use, distribution, and reproduction in any medium for non-commercial use provided the original author and source are credited.

\section{INTRODUCTION}

To reduce the under 5 mortality we need to decrease deaths due to pneumonia, which is the leading cause of death in children's excluding neonates [1].

Given the evolving understanding of 1 , $25(\mathrm{OH}) \mathrm{D}$ in the role of respiratory health and the potential of low vitamin $\mathrm{D}$ levels to be associated with increasing severity of acute respiratory illnesses, the goal of the current study was to compare serum $25(\mathrm{OH})$ D levels among hospitalized children with and without respiratory illnesses.

\section{AIM}

1. To compare status of serum vitamin $\mathrm{D}$ in children with respiratory illness versus children with nonrespiratory illnesses.
2. To find out the relationship of Vitamin D deficiency to occurrence of respiratory illness.

STUDY DESIGN: Analytical, Case control study.

\section{Methodology}

\section{Definitions of Respiratory Illness}

Since no single recognized classification exists to grade the severity of respiratory illnesses, Pneumonia was graded according to IMCI [2] and other respiratory diseases (asthma, bronchiolitis, etc.) were graded according to Clinical Respiratory Score [3]. 
CRS= CLINICAL RESPIRATORY SCORE [3]

\begin{tabular}{|l|l|l|l|}
\hline ASSESS & SCORE 0 & SCORE 1 & SCORE 2 \\
\hline Respiratory & $<2$ month: $<50$ & $<2$ month:50-60 & $2-12$ month:40-50 \\
Rate & $2-12$ month: $<40$ & $1-5$ years:30-40 & month: $>60$ \\
& $1-5$ years: $<30$ & 5 years:20-30 & month: $>50$ \\
& $>5$ years: $<20$ & Dears: $>40$ \\
& Depressed air movement, \\
Auscultation & $\begin{array}{l}\text { Good air movement, } \\
\text { expiratory scattered wheezing } \\
\text { or loose rales/crackles }\end{array}$ & $\begin{array}{l}\text { inspiratory and expiratory } \\
\text { wheezes or rales/crackles } \\
\text { sounds, severe wheezing or } \\
\text { rales/crackles, or marked } \\
\text { prolonged expiration }\end{array}$ \\
\hline $\begin{array}{l}\text { Use of } \\
\text { Accessory } \\
\text { Muscles }\end{array}$ & $\begin{array}{l}\text { Mild to no use of accessory } \\
\text { muscles, mild to no } \\
\text { retractions, nasal flaring on } \\
\text { inspiration }\end{array}$ & $\begin{array}{l}\text { Moderate intercostal } \\
\text { retractions, mild to moderate } \\
\text { use of accessory muscles, } \\
\text { nasal flaring }\end{array}$ & $\begin{array}{l}\text { Severe intercostal and sub sternal } \\
\text { retractions, nasal flaring }\end{array}$ \\
\hline Mental status & Normal to mildly irritable & Irritable, agitated, restless & Lethargic \\
\hline Room Air Sp0 $0_{2}$ & $>95 \%$ & $90-95 \%$ & $<90 \%$ \\
\hline Colour & Normal & Pale to normal & Cyanotic, dusky \\
\hline
\end{tabular}

Mild $=$ CRS $\leq 3$; Moderate $=$ CRS 4-6; Severe $=$ CRS 6-8; Impending or Actual Respiratory Arrest $=$ CRS 8-12

\section{Data Collection}

All data was recorded according to a standard questionnaire. As far as practical, the cases and controls were matched for basic data (age, sex, date of admission).

- Cases: 100 consecutive children fulfilling the inclusion criteria who could not be excluded out were included in the study.

- Controls: controls were selected preferably on the same date from the inpatients with no respiratory involvement and who were admitted primarily for some other complaints after matching age and sex.

Participants were divided under three widely used thresholds: $10 \mathrm{ng} / \mathrm{ml}, 25 \mathrm{ng} / \mathrm{ml}$ and 80 $\mathrm{ng} / \mathrm{ml}$. 25(OH) D levels from 25 to $80 \mathrm{ng} / \mathrm{ml}$ was taken as optimal.

For all cases and controls, the serum levels of vitamin $\mathrm{D}$ was estimated by electrochemiluminiscence method (Equipment used: Cobas 6000 / Cobas e 411 analyser) and level of deficiency was categorized as mild to moderate deficiency $(10-24 \mathrm{ng} / \mathrm{ml})$ and severe deficiency (less than $10 \mathrm{ng} / \mathrm{ml}$ ).

\section{Statistical Analysis}

Chi-square test was used for the difference of their distribution between two groups. T test was used to test the difference of mean between cases and controls when it was normally distributed and for other clinical variables Mann-Whitney $U$ non parametric test was used. Association of sex and vitamin D was assessed through Mann-Whitney U, test. Spearman's Correlation coefficient was used for Correlation between age \& vitamin D level Correlation between Vitamin D \& CRS. KruskalWallis test was used for difference of Vitamin D within the respiratory illness group. The associations \& correlations were considered statistically significant if the $p$ value $\leq 0.05$. All data were analyzed and processed on SPSS Version 22.0 on a Windows 10 operating system.

\section{RESULTS}

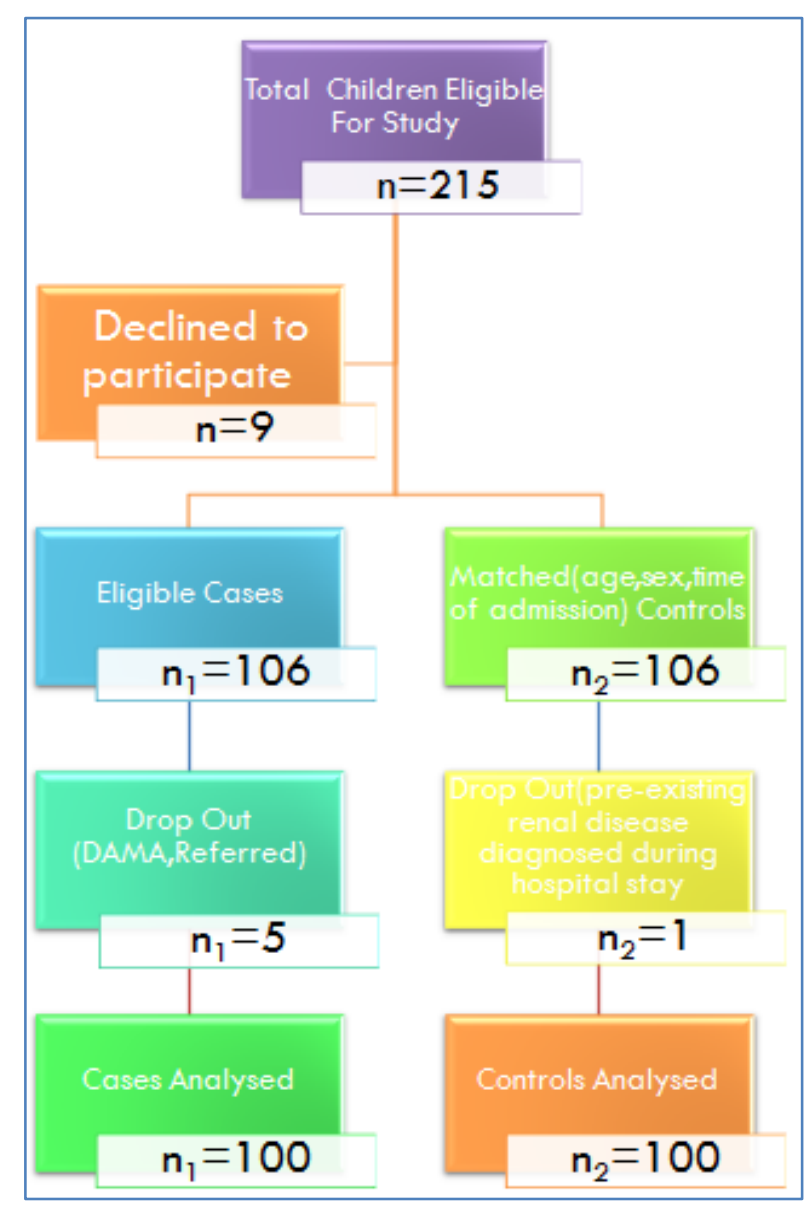

Fig-1: CONSORT Diagram of patients enrolled in the present study. 
Prateek Sinha et al; Sch J App Med Sci, Jan, 2021; 9(1): 14-20

Table-1

\begin{tabular}{|c|c|c|c|c|c|c|c|}
\hline \multirow[t]{2}{*}{ Measurements } & \multicolumn{2}{|c|}{ Cases(n=100) } & \multicolumn{2}{|c|}{ Controls(n=100) } & \multirow{2}{*}{$\begin{array}{l}\mathbf{P} \\
\text { value }\end{array}$} & \multicolumn{2}{|l|}{ Total } \\
\hline & Mean (SE) & $\begin{array}{l}95 \% \\
\mathrm{CI}\end{array}$ & Mean (SE) & $\begin{array}{l}95 \% \\
\mathrm{CI}\end{array}$ & & Mean (SE) & $\begin{array}{l}95 \% \\
\mathrm{CI}\end{array}$ \\
\hline Age (mo) & $16.99(1.5)$ & $\begin{array}{l}13.99- \\
19.98\end{array}$ & $18.9(1.42)$ & $\begin{array}{l}16.06- \\
21.73\end{array}$ & 0.35 & $17.94(1.03)$ & $\begin{array}{l}15.89- \\
19.99\end{array}$ \\
\hline Weight (kg) & $9.04(0.28)$ & $\begin{array}{l}8.48- \\
9.60\end{array}$ & $9.84(0.27)$ & $\begin{array}{l}9.30- \\
10.38\end{array}$ & 0.04 & $9.44(0.19)$ & $\begin{array}{l}9.05- \\
9.89\end{array}$ \\
\hline Height (m) & $0.75(0.01)$ & $\begin{array}{l}0.72- \\
0.77\end{array}$ & $0.78(0.01)$ & $\begin{array}{l}0.75- \\
0.80\end{array}$ & 0.09 & $0.76(0.00)$ & $\begin{array}{l}0.74- \\
0.78\end{array}$ \\
\hline Head CC (cm) & $44.19(0.31)$ & $\begin{array}{l}43.56- \\
44.82\end{array}$ & $45.04(0.23)$ & $\begin{array}{l}44.57- \\
45.51\end{array}$ & 0.03 & $44.62(0.20)$ & $\begin{array}{l}44.22- \\
45.01\end{array}$ \\
\hline $\begin{array}{l}\text { Mid arm CC } \\
(\mathrm{cm})\end{array}$ & $13.27(0.06)$ & $\begin{array}{l}13.15- \\
13.39\end{array}$ & $13.38(0.06)$ & $\begin{array}{l}13.25- \\
13.51\end{array}$ & 0.22 & $13.33(0.04)$ & $\begin{array}{l}13.24- \\
13.41\end{array}$ \\
\hline BMI & $15.72(0.11)$ & $\begin{array}{l}15.50- \\
15.95\end{array}$ & $15.94(0.11)$ & $\begin{array}{l}15.71- \\
16.17\end{array}$ & 0.18 & $15.83(0.08)$ & $\begin{array}{l}15.67- \\
15.99\end{array}$ \\
\hline Chest CC (cm) & $44.03(0.25)$ & $\begin{array}{l}43.53- \\
44.52\end{array}$ & $44.74(0.18)$ & $\begin{array}{l}44.38- \\
45.10\end{array}$ & 0.02 & $44.38(0.15)$ & $\begin{array}{l}44.08- \\
44.69\end{array}$ \\
\hline CRS & $9.46(0.16)$ & $\begin{array}{l}9.13- \\
9.78\end{array}$ & $1.93(0.12)$ & $\begin{array}{l}1.67- \\
2.18\end{array}$ & 0.00 & $5.69(0.28)$ & $\begin{array}{l}5.12- \\
6.26\end{array}$ \\
\hline
\end{tabular}

Table 1: Showing baseline characteristics of the cases $(\mathrm{N}=100)$ and controls $(\mathrm{N}=100)$.In the present study controls were age, sex and time matched children who were admitted with CRS $<5$. Table shows that the cases and controls were fairly well matched except for weight, head circumference and chest circumference and this difference is statistically significant $(\mathrm{p}<0.05)$.

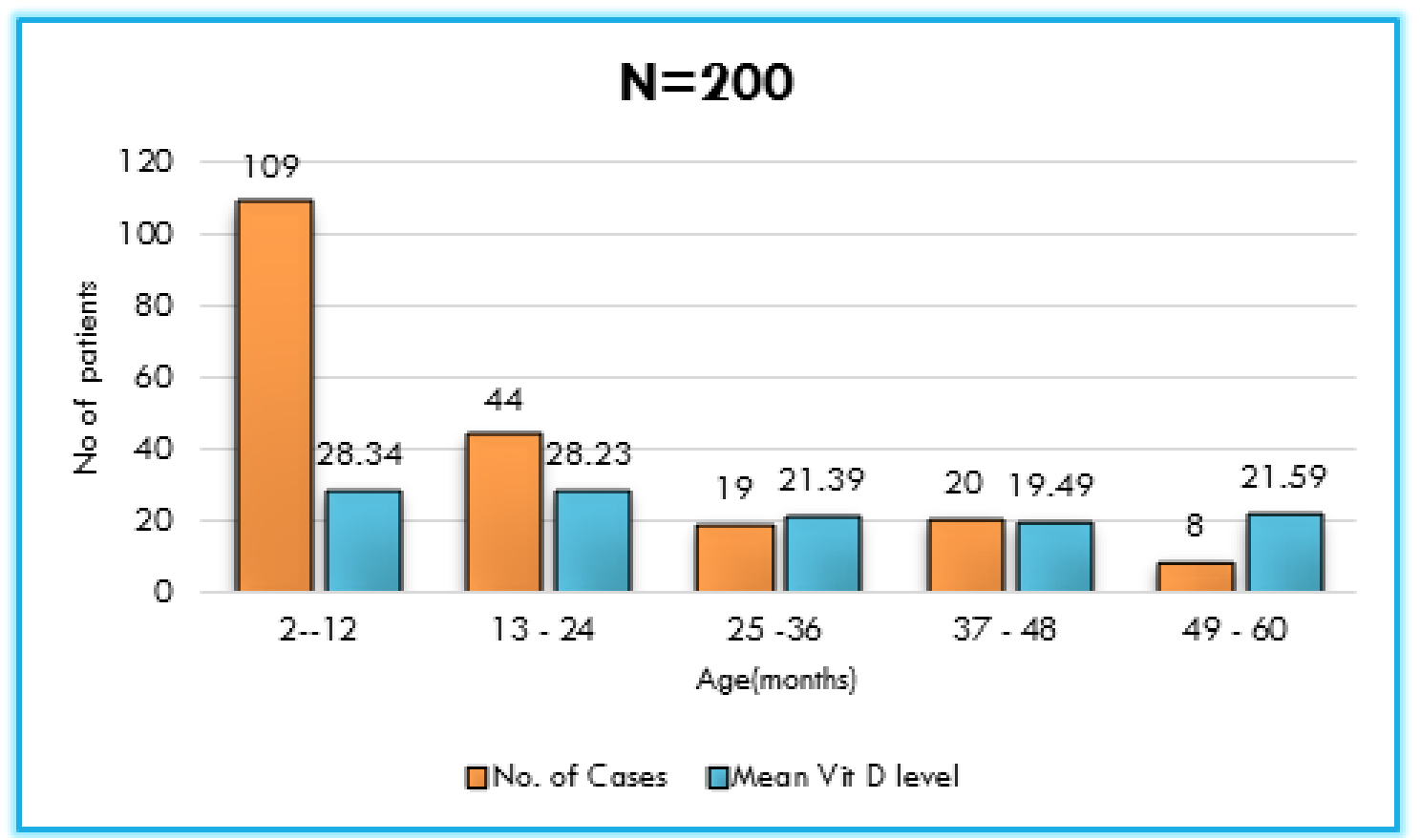

Fig-2: Showing age based Vitamin D level distribution of the study population. Spearman's Correlation coefficient for age \& vitamin d level was $\mathbf{- 0 . 2 0 4}$, P-Value was 0.004 (highly significant), suggesting correlation between Vitamin D levels \& age.

\section{Vitamin D Levels}

Vitamin D levels were normally distributed among the children enrolled in the present study population: the mean vitamin D level was $26.50 \mathrm{ng} / \mathrm{mL}$ (SE: 0.95 ) and the median vitamin D level was 26.27 $\mathrm{ng} / \mathrm{mL}$. Using an independent sample t test, the means for cases and controls were, respectively, $25.98 \mathrm{ng} / \mathrm{mL}$ and $27.02 \mathrm{ng} / \mathrm{mL}$. The p-value for risk of vitamin $\mathrm{D}$ deficiency leading to respiratory diseases was " 0.20 " using Pearson chi-square, which is non-significant. Odds ratio for respiratory illness in vitamin D deficiency versus non deficient was " 1.43 ". 
Table-2: Showing mean value of vitamin $D$ in cases \& controls $(N=100)$.

\begin{tabular}{|l|l|l|l|l|l|l|l|}
\hline \multirow{2}{*}{ Measurements } & \multicolumn{2}{|l|}{ Cases(n=100) } & \multicolumn{2}{l|}{$\begin{array}{l}\text { Controls(n=100) } \\
\text { value }\end{array}$} & \multicolumn{2}{l|}{ Total } \\
\cline { 2 - 5 } & Mean (SE) & $95 \%$ CI & Mean (SE) & $95 \%$ CI & & Mean (SE) & $95 \%$ CI \\
\hline Vit D & $25.98(1.45)$ & $23.10-28.87$ & $27.02(1.24)$ & $24.54-$ & $\mathbf{0 . 5 8}$ & $26.50(0.95)$ & $24.62-$ \\
Level(ng/ml) & & & & 29.50 & & & 28.39 \\
\hline
\end{tabular}

Table-3: Showing mean value of vitamin $D$ in morbidities of cases $(N=100)$. Mean value of Vitamin $D$ of the groups of Severe \& Very Severe Pneumonia were in deficient level.

\begin{tabular}{|l|l|l|ll|}
\hline Morbidity & $\begin{array}{l}\text { Mean Vitamin D } \\
\text { Level(ng/ml) }\end{array}$ & Std. Error( SE ) & \multicolumn{2}{|c|}{$\begin{array}{l}\text { 95\% Confidence Interval } \\
\text { for Mean }\end{array}$} \\
\hline Asthma & 26.34 & 2.60 & $\begin{array}{l}\text { Lower } \\
\text { Upper }\end{array}$ & 20.92 \\
& & & Lower & 22.85 \\
\hline Bronchiolitis & 32.61 & 4.60 & Upper & 42.38 \\
\hline Croup & & & Lower & 13.69 \\
& 31.49 & 6.41 & Upper & 49.29 \\
\hline Severe pneumonia & 22.07 & & Lower & 12.70 \\
& & 4.061 & Upper & 31.43 \\
\hline $\begin{array}{l}\text { Very severe } \\
\text { pneumonia }\end{array}$ & 23.76 & 2.045 & Lower & 19.64 \\
\hline
\end{tabular}

Table-4: Showing mean value of vitamin $D$ in morbidities of controls $(\mathrm{N}=100)$. Mean value of Febrile Convulsion \& FUO were in deficient level.

\begin{tabular}{|l|l|l|ll|}
\hline Morbidity & Mean Vit D(ng/ml) & Std. Error( SE ) & \multicolumn{2}{|c|}{ 95\% C I for Mean } \\
\hline Acute Dysentery & 24.605 & 2.40664 & Lower & 16.946 \\
& & & Upper & 32.264 \\
\hline $\begin{array}{l}\text { Acute Watery } \\
\text { Diarrhoea }\end{array}$ & 26.4813 & 2.59132 & Lower & 21.1815 \\
Febrile Convulsion & 24.3492 & & Upper & 31.7812 \\
\hline F U O & & 2.79223 & Lower & 18.2035 \\
& 22.9125 & 5.32834 & Upper & 30.4948 \\
\hline Rotavirus Enteritis & 31.065 & & Lower & 5.9554 \\
& & 3.01008 & Upper & 39.8696 \\
\hline SEPSIS Tract & 30.484 & 3.53633 & Lower & 24.2557 \\
& & & Upper & 37.8743 \\
\hline Urinary & 27.7089 & 4.15428 & Lower & 19.5541 \\
Infection & 29.1673 & & Upper & 35.8637 \\
\hline Viral Fever & & 3.34409 & Lower & 18.9499 \\
& & & Upper & 42.0181 \\
\hline
\end{tabular}

\section{Case-Control Study}

For the entire cohort, $49.5 \%$ of all children were vitamin D deficient and among them $14 \%$ were severe vitamin D deficient. The proportions of cases and controls who were vitamin D deficient (54\% vs $45 \%$, respectively; $\mathrm{P}=0.203$ ) did not differ significantly between groups.
When all patients with primary admission diagnosis of infectious processes were removed from the case \& control group, mean serum $25(\mathrm{OH})$ D levels did not differ between cases and controls (25.47 vs $24.39 \mathrm{ng} / \mathrm{mL}$, respectively; $\mathrm{P}=0.77)$, and the proportions of cases and controls who were vitamin D deficient $(45.45 \%$ of cases and $50.0 \%$ of controls; $\mathrm{P}$ $=0.48$ ) did not differ significantly. 


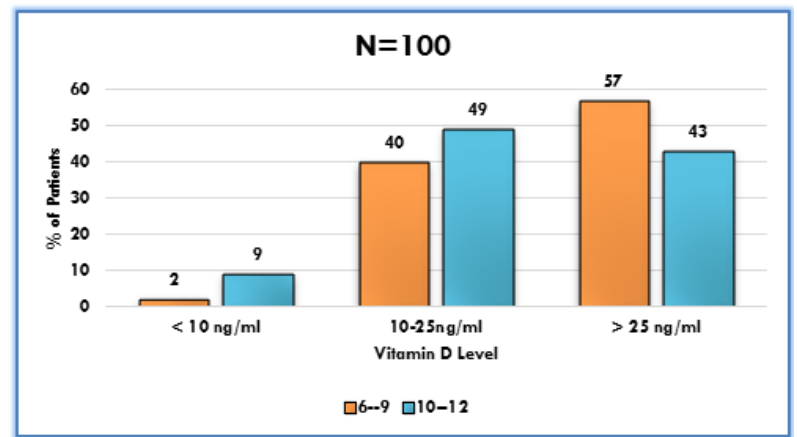

Fig-4: Shows Vitamin D level based on CRS .Severe Vitamin D deficiency was seen more with increase in CRS. Spearman's Correlation coefficient for CRS \& vitamin d level was $-\mathbf{0 . 1 3 6}, \mathbf{P}$-Value was 0.05 (significant), suggesting Vitamin D deficiency correlates with CRS score.

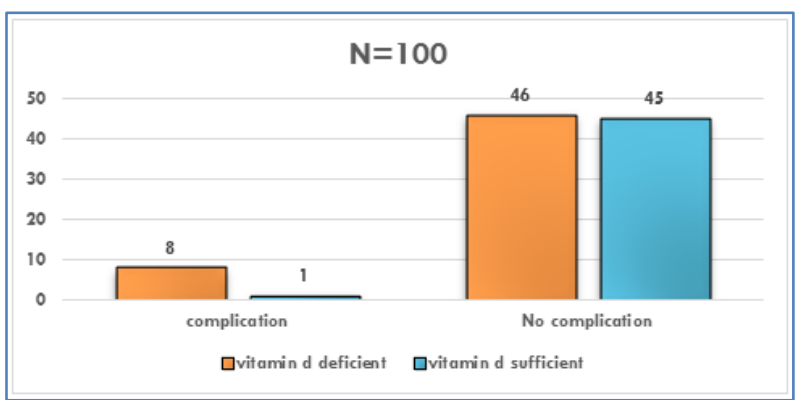

Fig-5: Shows complications in deficient \& sufficient groups. P-value calculated by chi- square test was “0.02" \& was significant, suggesting association between Vitamin D deficiency \& respiratory complication. Odds ratio was "7.7". Complications included empyema thoracis, pneumothorax $\&$ pleural effusion.

\section{DiscUSSION}

In the present study respiratory complications were found more in Vitamin D deficient group, P-value calculated by chi- square test was " 0.02 " \& was significant, suggesting association between Vitamin D deficiency \& respiratory complication. Odds ratio was "7.7.

Following studies done in India had mean Vitamin D level lower than the present study \& higher proportion of Vitamin D deficiency in their study population.

Mehrotra et al. [4] did a study in breastfed infants, 3 months in Delhi $\left(28.3^{\circ}\right) \&$ found all babies to be deficient with mean Vitamin D Level of 9.03 (SD-4.63).

Agarwal et al. [5] performed a study in infants, born low birth-weight, at 3 months in Delhi $\left(28.3^{\circ} \mathrm{N}\right) \&$ found $72.4 \%$ children to be deficient.

Bhalala et al. [6] performed a study in exclusively breastfed infants, 3 months old in
Mumbai $\left(18.9^{\circ} \mathrm{N}\right)$ \& found mean Vitamin D Level of 18.19 (SD-9.74).

Following studies done in India had mean Vitamin D level similar or higher than the present study \& lower proportion of Vitamin D deficiency in their study population.

Kadam et al. [7] performed a study in premenarchal school girls(8-12 years) in Pune $\left(18.5^{\circ} \mathrm{N}\right) \&$ found Vitamin D deficiency in $34.2 \%$ with mean level of 24.6 (SD-10.4).

Tiwari et al. [8] performed a study in slum children, age 9-30 months residing in Sundernagari area, Delhi $\left(28.3^{\circ} \mathrm{N}\right)$ in winter \& found mean Vitamin D Level of 38.52 (SD-10.28).

\section{Comparing with other similar case control studies from India}

Avinash Kumar, Ratan Gupta, P K Debata, Dinesh K Taneja, K C Aggarwal [9] from VMMC and Safdarjang hospital, New Delhi, India performed a study in children (5- 12 years) with Asthma as cases \& found mean Vitamin D Level in cases to be 15.0 as compared to controls 20.5 and this difference was highly significant $(\mathrm{p}<0.001) .77 .78 \%$ of cases \& $47.6 \%$ of controls were having low serum Vitamin D levels.

V Wayse, A Yousafzai, K Mogale and S Filteau [10] performed a similar study in Sanjeevani Paediatrics Hospital, a private hospital in Indapur, India in children (less than 5 years of age) with respiratory disease as cases \& found mean serum 25OHD3 22.8 $\mathrm{nmol} / \mathrm{l}$ in cases \& $38.4 \mathrm{nmol} / \mathrm{l}$ in controls and this difference was highly significant $(\mathrm{p}<0.001) .80 \%$ of cases \& $31 \%$ of controls were Vitamin D deficient.

\section{Comparing with other similar international case control studies}

Sabah Iqbal, Edward V. Mosenkis, Pankaj Jain, Andrew Wiles, Jennifer Lerner, Angela S. Benton, James M. Chamberlain \& Robert J. Freishtat [11] performed a study in hospitalized children (6 months to 12 years) at Children's National Medical Center in Washington, DC (latitude $38^{\circ}$ /longitude $55^{\prime}$ ), their result was similar to the present study, Vitamin D levels were normally distributed among their population: the mean vitamin D level was $26.6 \mathrm{ng} / \mathrm{mL}$ and the median vitamin D level was $26.3 \mathrm{ng} / \mathrm{mL}$. Skewness among the group as a whole was 0.404 (SE: 0.2), and kurtosis was -0.22 (SE: 0.47). Skewness was 0.13 (SE: 0.38) among cases and 0.56 (SE: 0.26) among controls. Kurtosis was -0.85 (SE: 0.75) among cases and 0.23 (SE: 0.52) among controls. The mean for cases and controls were, respectively, $26.8 \mathrm{ng} / \mathrm{mL}$ and $26.1 \mathrm{ng} / \mathrm{mL} \quad(\mathrm{P}=.73[95 \%$ 
Prateek Sinha et al; Sch J App Med Sci, Jan, 2021; 9(1): 14-20

confidence interval: -3.5 to 4.9$])$. $64.8 \%$ had vitamin $D$ insufficiency $(25[\mathrm{OH}]$ D level $\leq 30$ $\mathrm{ng} / \mathrm{mL}$ ) and $31.1 \%$ had vitamin $\mathrm{D}$ deficiency (25[OH] D level $\leq 20 \mathrm{ng} / \mathrm{mL})$. The proportions of cases and controls who were vitamin D insufficient $(57.9 \%$ vs $68.7 \%$, respectively; $\mathrm{P}=.30)$ and vitamin D deficient (34.2\% vs 30\%, respectively; $\mathrm{P}$ $=.67)$ did not differ significantly between groups. Mean serum 25(OH) D levels also did not differ between cases and controls $(26.8 \pm 11.5$ vs $26.1 \pm$ $10.6 \mathrm{ng} / \mathrm{mL}$, respectively; $\mathrm{P}=.73)$.

McNally JD, Leis K, Matheson LA, Karuananyake C, Sankaran K, Rosenberg AM [12] performed a age matched case control in Royal University Hospital, Saskatoon, Saskatchewan, Canada to find Vitamin D deficiency in young children with severe acute lower respiratory infection. No difference was observed in vitamin D levels between the entire ALRI group and control groups (mean vitamin D level 81 vs. $83 \mathrm{nmol} / \mathrm{L}$, respectively); however, significantly more children admitted to the paediatric intensive care unit with ALRI were vitamin $\mathrm{D}$ deficient.

Roth DE, Shah R, Black RE, Baqui AH [13] performed a matched (age, sex, village) case control study in Sylhet, Bangladesh in Children aged 1-18 months hospitalized with ALRI, Mean 25(OH)D was significantly lower among ALRI cases than controls (29.1 nmol/L vs. $39.1 \mathrm{nmol} / \mathrm{L} ; \mathrm{p}=0.015)$.

Oduwole AO, Renner JK, Disu E, Ibitoye E, Emokpae E [14] performed a case control study to find the relationship between vitamin D levels and outcome of pneumonia in children in Nigeria. Amongst the cases 54\% had serum 25OHD less than $70 \mathrm{nmol} / \mathrm{L}$ and $13 \%$ had levels below 40 nmol/L. Empyema thoracis and death occurred amongst the two subjects with $25 \mathrm{OHD}$ between 27.5 and $40 \mathrm{nmol} / \mathrm{L}$.

Inamo $\mathrm{Y}$, Hasegawa $\mathrm{M}$, Saito $\mathrm{K}$, Hayashi R, Ishikawa T, Yoshino Y, Hashimoto K, Fuchigami T [15] performed a study in Nihon University NerimaHikarigaoka Hospital, Japan and found Significantly more children with ALRI who needed supplementary oxygen and ventilator management were vitamin D deficient. These findings suggested that the immunomodulatory properties of vitamin D may influence the severity of ALRI.

In the present study Spearman's Correlation coefficient for age \& vitamin D level was -0.204, PValue was 0.004 (highly significant), suggesting correlation between Vitamin D levels \& age similar findings were seen in the study done by Sabah Iqbal, Edward V. Mosenkis, Pankaj Jain, Andrew Wiles, Jennifer Lerner, Angela S. Benton, James M. Chamberlain \& Robert J. Freishtat [11], across both cases and controls, an increase of 1 year in age was associated with a $0.92 \pm 0.16$ decrease in $25(\mathrm{OH}) \mathrm{D}(\mathrm{P}<$ $.001)$. Opposite findings were seen in study by $\mathrm{V}$ Wayse, A Yousafzai1, K Mogale and S Filteau [10], Serum 25OHD3 increased significantly with age. The correlation between natural $\log 25 \mathrm{OHD} 3$ and age in months appeared stronger for control $(\mathrm{r}=0.72, \mathrm{P}<0.001)$ than for case children $(\mathrm{r}=0.31, \mathrm{P}<0.05)$.

\section{SuMMARY AND CONCLUSION}

\section{Summary}

Following are the findings obtained:

1. The mean age of total patients in the study was 17.9 months. The mean age of all male patients enrolled was 17.3 months and the mean age of the female patients enrolled was 18.5 months.

2. No association between sex \& vitamin D deficiency was found in the present study, p-value for association between gender \& vitamin D deficiency was " 0.381 "; thus non-significant.

3. Percent of cases and controls who were vitamin D deficient was $54 \%$ vs $45 \%$, respectively.

4. Respiratory complications were found more in Vitamin D deficient group, P-value was “ 0.02 " \& was significant, suggesting association between Vitamin D deficiency \& respiratory complication. Odds for complications was "7.7"times more in Vitamin D deficient group compared to sufficient group.

5. Mean Vitamin D level in children aged 2-12 month, 13-24 month, 25-36 month, 37-48 month \& 49 to 60 month was $28.34,28.23,21.39,19.49$ \& 21.59 respectively. Correlation was found between age \& vitamin D level, P-Value was 0.004 (highly significant), suggesting association between Vitamin D levels \& age.

6. Severe Vitamin D deficiency was seen more with increase in CRS, P-Value was 0.05 (significant), suggesting Vitamin D deficiency correlates with CRS score.

7. $45 \%$ of asthma patients, $35 \%$ of bronchiolitis patients, $60 \%$ of patients with laryngotracheobronchitis, $67 \%$ of severe pneumonia patients \& $59 \%$ of very severe pneumonia patients were Vitamin d deficient.

8. Mean value of Vitamin D of the groups of Severe \& Very Severe Pneumonia were in deficient level.

9. Mean value of Febrile Convulsion \& Fever of unknown origin were in deficient level.

\section{CONCLUSION}

The present study compared the Vitamin D status of hospitalised children with respiratory \& non respiratory illnesses. No significant relationship was found between vitamin $D$ levels with any of the following: respiratory illnesses vs non respiratory, male vs females. Respiratory complications were found more in Vitamin D deficient group. Correlation was found between age \& vitamin D level, suggesting association 
Prateek Sinha et al; Sch J App Med Sci, Jan, 2021; 9(1): 14-20

between Vitamin D levels \& age. Severe Vitamin D deficiency was seen more with increase in CRS, suggesting Vitamin D deficiency correlates with CRS score.

\section{DECLARATION}

Principal Investigator: Dr. Prateek Sinha, Coinvestigators: Dr. Santanu Deb, Dr. Palash R Gogoi. Source of funding: Nil

Conflicts of interest: Nil

Financial association: Nil

Ethical approval: Our study was approved by the hospital ethics committee.

\section{REFERENCES}

1. Committing to Child Survival: A Promise Renewed Progress Report 2013 [Internet]. [cited 2015 Dec 13]. Available from: http://www.unicef.org/publications/files/APR_Prog ress_Report_2013_9_Sept_2013.pdf

2. Ghai OP, Paul Vinod K BA. Essential Pediatrics;CBS Publishers \& Distributors; World Health Organization; P-743

3. Texas children hospital. Evidence-based clinical outcomes decision support. Asthma/recurrent wheezing management clinical guideline. 2008.

4. Mehrotra P, Marwaha RK, Aneja S, Seth A, Singla BM, Ashraf G. Hypovitaminosis D and hypocalcemic seizures in infancy. Indian Pediatr. 2010;47:581-6.

5. Agarwal R, Virmani D, Jaipal ML, Gupta S, Gupta N, Sankar MJ. Vitamin D status of low birth weight infants in Delhi: a comparative study. J Trop Pediatr. 2012;58(6):446-50.

6. Bhalala U, Desai M, Parekh P, Mokal R, Chheda B. Subclinical hypovitaminosis D among exclusively breastfed young infants. Indian Pediatr. 2007;44(12):897-901.

7. Kadam NS, Chiplonkar SA, Khadilkar AV, Fischer PR, Hanumante NM, Khadilkar VV. Modifiable factors associated with low bone mineral content in underprivileged premenarchal Indian girls. J
Pediatr Endocrinol Metab. 2011;24(11-12):975-81.

8. Puliyel LTJM. Indian Pediatrics - Editorial. Idianpediatrics. 2004: 1076-7.

9. Avinash Kumar, Ratan Gupta, PK Debata, Dinesh $\mathrm{K}$ Taneja KCA. Levels of vitamin $\mathrm{d}$ in patients of childhood asthma. Pediatr oncall. 2014;11(4):1027.

10. Wayse V, Yousafzai A, Mogale K, Filteau S. Association of subclinical vitamin D deficiency with severe acute lower respiratory infection in Indian children under 5 y. Eur J Clin Nutr [Internet]. 2004;58(4):563-7. Available from: http://www.ncbi.nlm.nih.gov/pubmed/15042122.

11. Iqbal S, Mosenkis E V, Jain P, Wiles A, Lerner J, Benton AS. Vitamin d in pediatric inpatients with respiratory illnesses. Hosp Pediatr. 2013;3(4):3716.

12. McNally JD, Leis K, Matheson LA, Karuananyake C, Sankaran K, Rosenberg AM. Vitamin D deficiency in young children with severe acute lower respiratory infection. Pediatr Pulmonol [Internet]. 2009 Oct [cited 2015 Dec 28];44(10):981-8. Available from: http://www.ncbi.nlm.nih.gov/pubmed/19746437

13. Roth DE, Shah R, Black RE, Baqui AH. Vitamin D status and acute lower respiratory infection in early childhood in Sylhet, Bangladesh. Acta Paediatr. 2010 Mar;99(3):389-93.

14. Oduwole AO, Renner JK, Disu E, Ibitoye E, Emokpae E. Relationship between vitamin D levels and outcome of pneumonia in children. West Afr J Med [Internet]. Jan [cited 2015 Dec 28];29(6):3738. Available from: http://www.ncbi.nlm.nih.gov/pubmed/21465443

15. Inamo $Y$, Hasegawa $M$, Saito $K$, Hayashi $R$, Ishikawa T, Yoshino Y. Serum vitamin D concentrations and associated severity of acute lower respiratory tract infections in Japanese hospitalized children. Pediatr Int [Internet]. 2011 Apr [cited 2016 Jan 7];53(2):199-201. Available from: http://www.ncbi.nlm.nih.gov/pubmed/21648117. 